\title{
Life on the beach for a sand crab (Emerita rathbunae) (Decapoda, Hippidae): parasite-induced mortality of females in populations of the Pacific sand crab caused by Microphallus nicolli (Microphallidae)
}

\author{
Juan Violante-González ${ }^{1}$, Scott Monks², Guadalupe Quiterio-Rendon², Sergio García-Ibáñez ${ }^{1}$, \\ Edvino Larumbe-Morán ${ }^{3}$, Agustín A. Rojas-Herrera ${ }^{1}$ \\ 1 Unidad Académica de Ecología Marina, Universidad Autónoma de Guerrero, Gran Vía Tropical No. 20, Fracc. Las Playas, C.P. 39390, Acapulco, \\ Guerrero, México \\ 2 Centro de Investigaciones Biológicas, Universidad Autónoma del Estado de Hidalgo, Apartado Postal 1-10, C.P. 42001, Pachuca, Hidalgo, México \\ 3 Centro de Estudios Tecnológicos del Mar No 16, Interior Isla del Cayacal s/n, Zona Industrial, Cd. Lázaro Cárdenas, C.P. 60950, Michoacán, México
}

http://zoobank.org/499E17E0-C26D-47D1-A479-02B5077849B6

Corresponding author: Scott Monks (monks.scott@gmail.com)

Received 24 February 2016

Accepted 23 August 2016

Published 8 September 2016

Academic editor:

Michael Ohl

\section{Key Words}

helminth parasite

parasite-mediated mortality of hosts

parasite population parameters

Guerrero State

Mexican coast

\begin{abstract}
Parasites, by definition, can affect mortality of their host, making parasitism an important biotic determinant of animal population dynamics and community structure. Reduction in the number of larger, reproductive age females in populations of the Pacific sand crab, Emerita rathbunae (Decapoda, Hippidae), was observed in studies of the helminth community of this host. The aim of this study was to determine if high abundance of the metacercaria of the trematode, Microphallus nicolli (Microphallidae), causes mortality in this host. Females of E. rathbunae were collected from four sandy beaches in Guerrero State, Mexico, and helminths were collected from each crab. An analysis of variance (Anova) was applied to these data in order to identify differences in abundance between sizes of crabs, and an analysis of covariance (Ancova) was applied to identify differences in the abundance of metacercariae between locations. Parasite-related mortality was inferred by a decrease in abundance in older hosts. Linear and polynomial regressions of mean abundance of helminths $(\log \mathrm{x}+1$ transformed data) $v s$. cephalothorax length of crabs were significant for the four populations of E. rathbunae, indicating increased mortality of older, more heavily infected female crabs and resultant removal from the population. Encapsulation and melanization of cysts by crabs was observed, indicating that an immune response by crabs also killed a portion of the cysts from subsequent exposures. Mortality of hosts through behavioral modification favoring transmission of highly infected crabs was suggested as the driving force behind this process.
\end{abstract}

\section{Introduction}

Parasitism is an important biotic determinant of animal population dynamics and community structure. Parasites can influence host numbers within a population by either decreasing recruitment rate (by reducing host fecundity) or increasing mortality rate. Host mortality attributable to parasites can occur as a reduction in host survival due to the pathological consequences of parasitic infection, or as alterations in a host's phenotype and/or behavior to facilitate parasite transmission to definitive hosts via predation (Hansen and Poulin 2005; Koehler and Poulin 2010; Latham and Poulin 2002c; Poulin 1999; Thomas et al. 1995).

Several approaches based on statistical evidence have been used in a number of studies in an attempt to determine if infection with parasites affects host mortality rates in natural populations (Koehler and Poulin 2010; Latham and Poulin 2002c; Thomas et al. 1995). A frequent feature of many models is that host mortality rises as parasite load increases (Koehler and Poulin 2010; Latham and Poulin 2002c). In a system where the host continues 


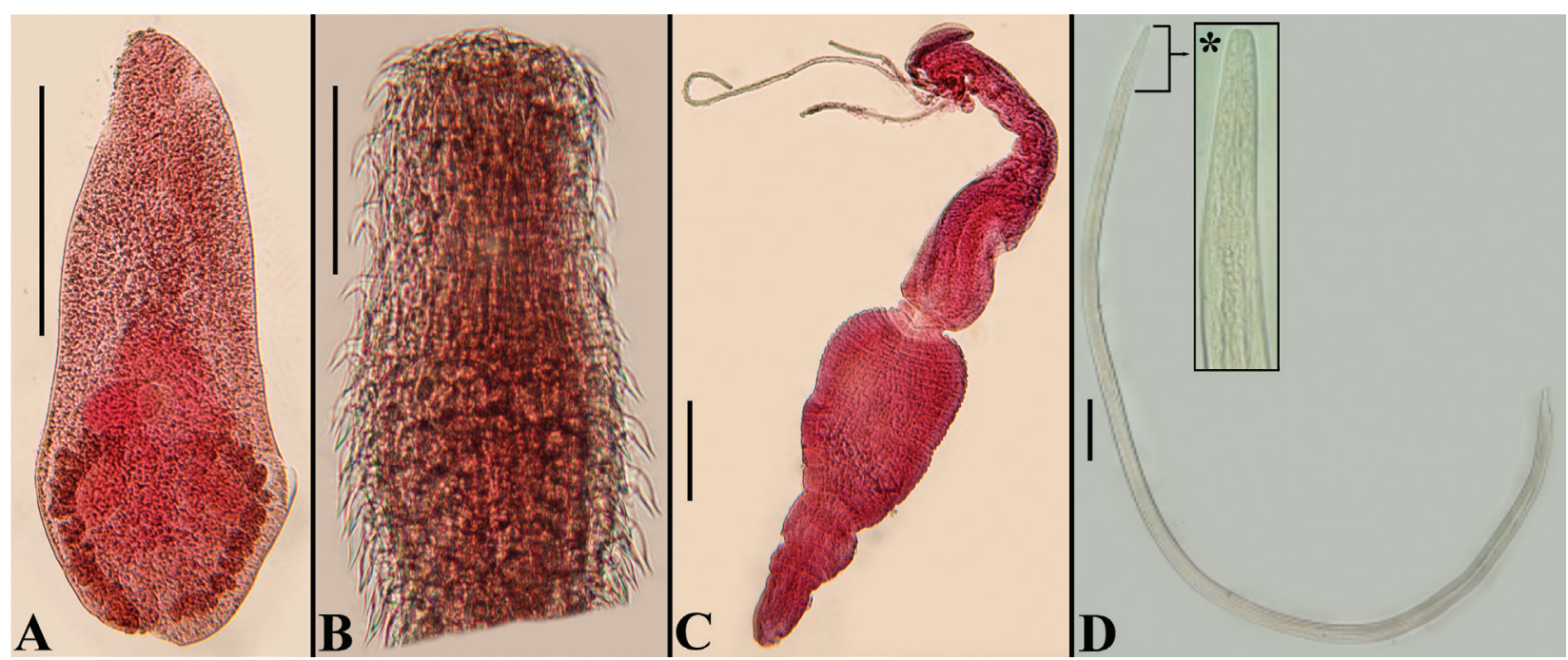

Figure 1. Helminth parasites of Emerita rathbunae. A Microphallus nicolli; B Everted proboscis of an excysted specimen of Profilicollis sp.; C Cestode larva; D Proleptus sp., inset $\left(^{*}\right)=$ anterior end of worm. Scale bars: A $=500 \mu \mathrm{m} ; \mathbf{B}=200 \mu \mathrm{m} ; \mathbf{C}=100 \mu \mathrm{m}$; $\mathbf{D}=100 \mu \mathrm{m}$.

to accumulate parasites over time, and assuming no density-dependent regulation of parasite numbers, older individuals can be expected to have higher average parasite loads than younger hosts. In some cases, however, older hosts have fewer parasites on average than intermediate age hosts, suggesting that more heavily infected individuals are removed from the host population by some effect of the parasites (Koehler and Poulin 2010; Latham and Poulin 2002c; Thomas et al. 1995).

The Pacific sand crab, or mole crab, Emerita rathbunae Schmitt, 1935 is common in the splash zone of sandy beaches in the intertidal zone (Hendrickx and Harvey 1999; Ríos-Elósegui and Hendrickx 2015). It is a good model for parasitological studies due to its wide geographical distribution, from the southeastern Gulf of California, Mexico, to the southern coast of Ecuador (Tam et al. 1996), and its importance in the macrofauna food chain of sandy beaches, where it can be very abundant (Oliva et al. 2008). A number of studies on the parasites of E. analoga have been made (Alvitres et al. 1999; Iannacone et al. 2007; Oliva et al. 2008; Oliva et al. 1992; Smith 2007), but only one study of the parasites of E. rathbunae (reported as E. analoga) has been made in Mexico (Violante-González et al. 2012; Violante-González et al. 2015). In that study, the authors (Violante-González et al. 2012; Violante-González et al. 2015) found that specimens of E. rathbunae inhabiting the coasts of Guerrero were parasitized by four species of larval helminth: one metacercariae [Microphallus nicolli (Cable and Hunninen, 1938)]; one cystacanth (Profilicollis sp.); one cestode (Trypanorhyncha); and one nematode (Proleptus sp.) (Fig. 1A-D). Infection levels of M. nicolli were significantly higher than reported for populations of $E$. analoga (hundreds to thousands per infected crab) from another North American location (Smith 2007). This suggested that these helminths have the potential to exert a substantial effect on populations of E. rathbunae. The objective of the present study was to test that hypothesis and determine if high abundance of $M$. nicolli in populations of E. rathbunae on the coasts of Guerrero, Mexico, effects mortality rates of this species of host in a manner reported for other species of crustacean at other locations.

\section{Materials and methods}

\section{Sampling}

The Mexican Pacific coastal region experiences two distinct climatic seasons, a rainy period from June to November (precipitation $\approx 430 \mathrm{~mm}$ ), and a dry season from December to May (precipitation $<70 \mathrm{~mm}$ ). Adult females of $E$. rathbunae (Table 1) were collected from four sandy beaches on the Pacific Coast of Guerrero, Mexico, between August and December 2009: San Andrés (16 $42^{\prime}$ N, 99 $40^{\prime} \mathrm{W}, n$ = 146); Revolcadero (16 $\left.{ }^{\circ} 47^{\prime} \mathrm{N}, 9^{\circ} 47^{\prime} \mathrm{W}, n=114\right)$; Las Trancas (16 $\left.6^{\circ} 59^{\prime} \mathrm{N}, 100^{\circ} 13^{\prime} \mathrm{W}, n=173\right)$; and Ixtapa (17'39' $\mathrm{N}, 101^{\circ} 36^{\prime} \mathrm{W}, n=68$ ) (Fig. 2). Males of E. rathbunae are much smaller than females, and measure from 2-14 mm (i.e., dwarf males), and they generally remain attached to the coxa of the female's pleopods, or they are located among the eggs (Ríos-Elosegui and Hendrickx 2015). Therefore, due to their small size they were not considered for this study.

Female crabs were captured by hand, placed in labeled plastic bags and transported to the laboratory of the Unidad Académica de Ecología Marina, Universidad Autónoma de Guerrero, Acapulco. Before dissection, cephalothorax length (CL in $\mathrm{mm}$ ) was measured to the nearest 0.1 millimeter using a digital caliper. This parameter was treated as the standard crab size in the analyses. Crabs were dissected by first removing the carapace, and then examining the internal structures, hepatopancreas, stomach, intestine, and muscle tissue, for helminths. Helminths were collected using standard practices and processed 
Table 1. Infection parameters of metacercariae of Microphallus nicolli in Emerita rathbunae from four coastal locations in Guerrero, Mexico. Significant values for the relationship between crab size (cephalothorax length) and metacercariae abundance per infected host $\left(\mathrm{r}_{\mathrm{s}}\right)$ are in bold. P $(\%)=$ Prevalence of infection ( $\%$ of infected crabs); Range of Intensity = minimum and maximum number of metacercariae; $r_{s}=$ Spearman's correlation coefficient.

\begin{tabular}{l|l|c|c|c|c|c|c|c}
\hline Date (2009) & Locality & No. of crabs & $\begin{array}{c}\text { Cephalothorax } \\
\text { length }(\mathbf{m m})\end{array}$ & $\begin{array}{c}\text { Total number } \\
\text { of parasites }\end{array}$ & $\mathbf{P}(\mathbf{\% )}$ & $\begin{array}{c}\text { Mean abundance of } \\
\text { metacercariae }\end{array}$ & $\begin{array}{c}\text { Range of } \\
\text { Intensity }\end{array}$ & $\mathbf{r}_{\mathbf{s}}$ \\
\hline Sep. & San Andrés & 146 & $37.6 \pm 2.9$ & 40,3414 & 100 & $2763.1 \pm 1235.6$ & $300 \cdot 6000$ & $\mathbf{0 . 2 0 8}$ \\
\hline Oct. & Revolcadero & 114 & $34.2 \pm 1.7$ & 107,921 & 100 & $946.7 \pm 796.8$ & $103 \cdot 4235$ & $\mathbf{0 . 6 0 9}$ \\
\hline Nov. & Las Trancas & 173 & $38.2 \pm 2.2$ & 403,177 & 100 & $2330.5 \pm 1076.8$ & $1050 \cdot 5800$ & $\mathbf{0 . 4 4 4}$ \\
\hline Dec. & Ixtapa & 68 & $32.9 \pm 5.6$ & 58,241 & 100 & $856.5 \pm 597.5$ & $15 \cdot 2550$ & $\mathbf{0 . 6 8 9}$ \\
\hline
\end{tabular}

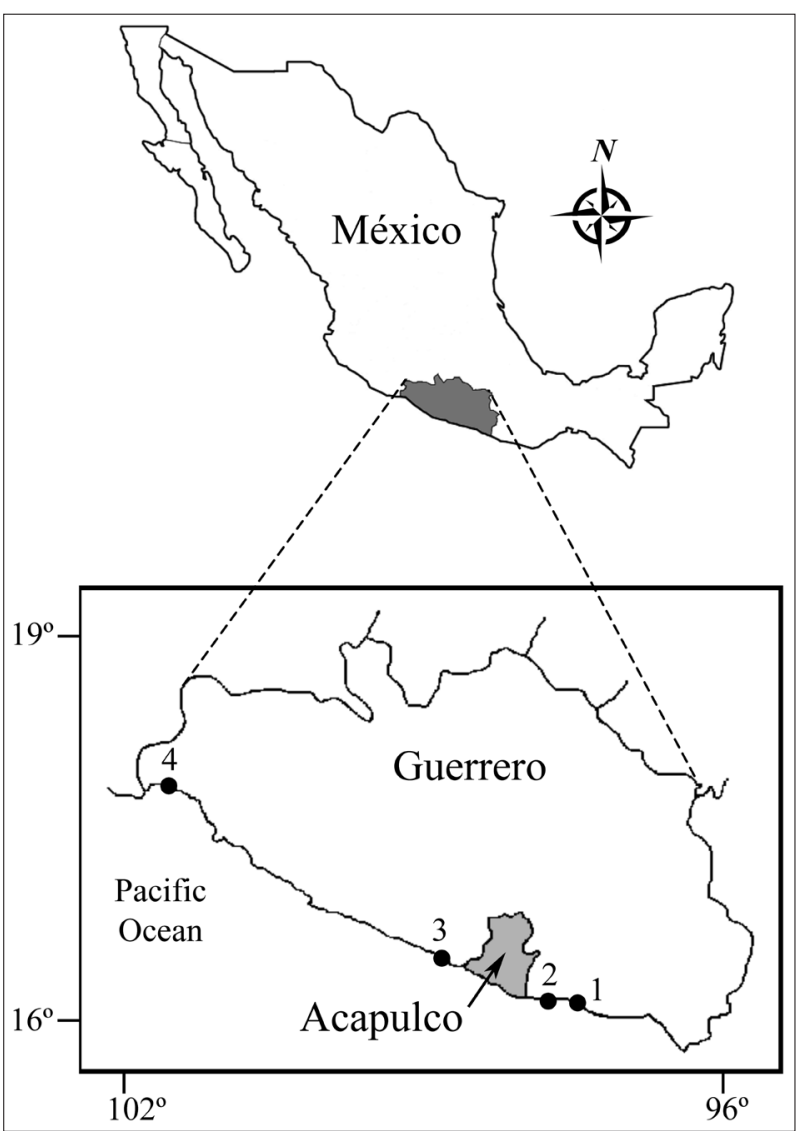

Figure 2. Map indicating the four collection localities along the Pacific coast of Guerrero. 1. San Andres; 2. Revolcadero; 3. Las Trancas; 4. Ixtapa.

for identification (Pritchard and Kruse 1982). Infection parameters included prevalence (percent infected hosts); abundance (number of parasites per examined host) expressed as the mean \pm standard deviation; range of intensity (Bush et al. 1997); and volumetric abundance (volume of live metacercariae of all development stages per host, in $\mathrm{mm}^{3}$ ) (see Violante-González et al. 2015 for discussion of these data). Vouchers of specimens were deposited in the Colección de Helmintos, Universidad Autónoma del Estado de Hidalgo, Mexico (CHE-F-0019).

\section{Statistical analyses}

Infection parameters included prevalence (percent of infected hosts); abundance (number of parasites per exam- ined host) expressed as the mean \pm standard deviation; range of intensity (Bush et al. 1997); and volumetric abundance (volume of live metacercariae of all developmental stages per host, in $\mathrm{mm}^{3}$ ). An analysis of variance (Anova) was applied to identify differences in sizes of the crabs, and an analysis of covariance (Ancova) was applied to identify differences in the abundance of metacercariae between locations. Data were log-transformed when significant deviations from normality were identified. Correlations were calculated using the Spearman range coefficient $\left(r_{s}\right)$. Significance for all the statistical analyses was established at $P=0.05$, unless stated otherwise. The software SPSS (Version 20) was used for all statistical analyses.

Size varied among the encysted metacercariae of $M$. nicolli, and a number of melanized cysts were found in each infected crab, so samples of cysts were measured (length and maximum width in $\mu \mathrm{m}$ ) using an ocular micrometer for two locations (San Andrés and Las Trancas; $n=866$ ). These measurements were used to calculate the volume of live cysts $\left(\mathrm{mm}^{3}\right)$ using the volume formula for a scalene ellipsoid [V $=(4 / 3) \pi(a / 2)(b / 2)(c / 2)$ where $a$ is cyst length, $b$ is cyst width, and $c$ is cyst height]. Melanized cysts were considered to contain dead metacercaria (Bryan-Walker et al. 2007; Koehler and Poulin 2010). Cysts also were classified into four categories based on size and characteristics (live or dead/melanized), following a modified version of the classification reported by Keeney et al. (2007): 1. = immature cyst (small); 2 . $=$ late immature (medium); 3. = mature (large); and 4. = melanized (dead). Crabs from San Andrés and Las Trancas were pooled and divided arbitrarily into 6 equal (2.1 $\mathrm{mm}$ ) size-classes in order to describe cyst distribution by size (cephalothorax length $=\mathrm{CL}$ ) of crabs.

Mean parasite load (total number of live metacercariae of all sizes/total number of crabs that were examined) was plotted versus size-class of crabs for the four localities in order to evaluate the affect of this parameter on host mortality; a close relationship was assumed between age and size (Latham and Poulin 2002b). The variance to mean abundance ratio, a measure of parasite aggregation (Bush et al. 1997), was calculated to determine variation in infection levels by host size-class. Differences in mean parasite abundance and the variance to mean abundance ratio were analyzed as a function of increasing size class. Linear and polynomial (curvilinear) regressions were 
then fitted using the log-transformed data $(\log x+1)$ of mean parasite abundance (dependent variable) and CL (independent variable), by location. The regressions providing the best fit for the data were selected using the highest coefficient of determination $\left(\mathrm{r}^{2}\right)$ value and a substantially low $P$ value for each regression (Latham and Poulin 2002b).

\section{Results}

The total sample size was 591 female crabs (E. rathbunae), ranging from 68 individuals at Ixtapa to 173 at Las Trancas (Table 1). Cephalothorax length was significantly different between collection locations: $32.9 \mathrm{~mm}$ $\pm 5.6 \mathrm{~mm}$ (Ixtapa) to $38.2 \mathrm{~mm} \pm 2.2 \mathrm{~mm}$ (Las Trancas) (Anova, $\mathrm{F}=80.8, P<0.0001$ ) (Table 1). Encysted metacercariae (Fig. 3) of M. nicolli were recovered largely from the hepatopancreas of infected crabs. Prevalence of M. nicolli was $100 \%$ at all four locations, although mean abundance varied from 857 metacercariae/crab \pm 598 metacercariae (Ixtapa) to 2,763 metacercariae/crab $\pm 1,236$ metacercariae (San Andrés, Table 1) (Ancova, $F=43.62$, $P=0.0001)$.

Cephalothorax length was correlated positively with abundance of metacercariae at all locations $(P<0.05)$, although correlation coefficient values $\left(\mathrm{r}_{\mathrm{s}}\right)$ were low in most cases (Table 1). The overall percentage of live (unmelanized) cyst decreased as the developmental stage progressed from immature to mature cysts (Table 2). The percentage of melanized cysts corresponded to the three previous development stages, although the general cyst

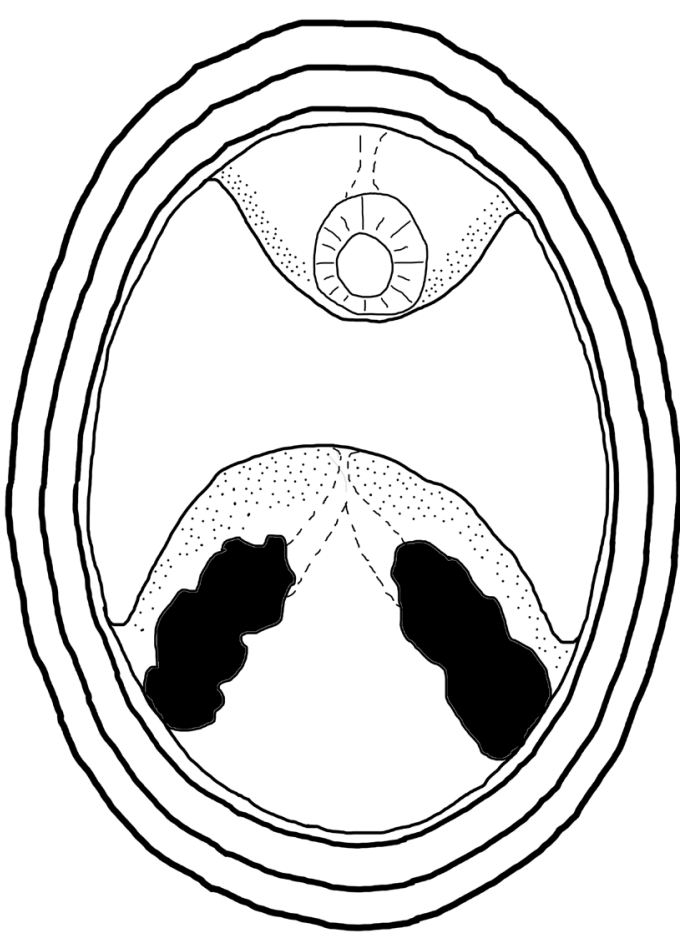

Figure 3. Cyst of an older metacercaria of Microphallus nicolli. Scale bar: $100 \mu \mathrm{m}$ pattern remained unchanged, i.e., all crabs had a higher percentage of immature than mature but melanized cysts.

Distribution of cysts, based on developmental stage and crab size, did not differ at the two locations where this was analyzed (San Andrés and Las Trancas). The percentage of mature cysts decreased as crab size increased, and the percentage of melanized cysts increased with the increase (small to large) in the size of crabs (Fig. 4A, B). Mean volumetric abundance of metacercariae, considering the three developmental stages, decreased in the largest size classes of crabs at both locations (Fig. 5A, B).

Linear and polynomial regressions of the relationship between mean abundance of helminths $(\log x+1)$ and cephalothorax length of crabs were significant at all four beaches (Table 3). However, the coefficients of determination $\left(r^{2}\right)$ values for the polynomial regressions were higher, indicating that the curvilinear regressions provided a better fit to the data. Mean abundance of M. nicolli plotted against crab size-class produced a convex curve in the San Andrés and Ixtapa populations, indicating that cyst number tended to decline in the largest size-classes (Fig. 6A, D). In contrast, the curves generated for Revolcadero and Las Trancas were concave (Fig. 6B, C). The degree of parasite aggregation was lower in the largest size-classes at San Andrés and Ixtapa (Fig. 6A, D), which coincides with the convex curves produced by the polynomial regressions for these two locations.

\section{Discussion}

Species of Microphallus infect several species of marine crustaceans that function as second intermediate hosts; adult worms mature mainly in coastal birds (Hansen and Poulin 2005; Pina et al. 2011). The metacercariae exhibit high infection site-specificity and encyst mainly in the hepatopancreas of crabs, where they reach high prevalences (Hansen and Poulin 2005; Koehler and Poulin 2010; Pina et al. 2011; Robaldo et al. 1999). In crustaceans, the hepatopancreas is the main organ involved in carbohydrate metabolism (glucose and glycogen), which means that it provides greater availability of energy resources (nutrients) for establishment of helminths (Robaldo et al. 1999). All (100\%) of the specimens of $E$. rathbunae from the four locations were infected with $M$. nicolli, recovered mainly from the hepatopancreas, confirming the expectation of a strong habitat specificity for members of this genus (Koehler et al. 2011).

Although prevalence of $M$. nicolli did not differ between the four locations, mean abundance was significantly higher at San Andrés and Las Trancas (Table 1) than at the other two locations. Temporal and spatial variations in levels of infection in intermediate hosts are commonly observed patterns in studies of parasite ecology (Latham and Poulin 2002b; Oliva et al. 2008; Smith 2007; Studer and Poulin 2012). Spatial variation in the level of infection such as that observed here has been attributed by other authors to differences in abundances 

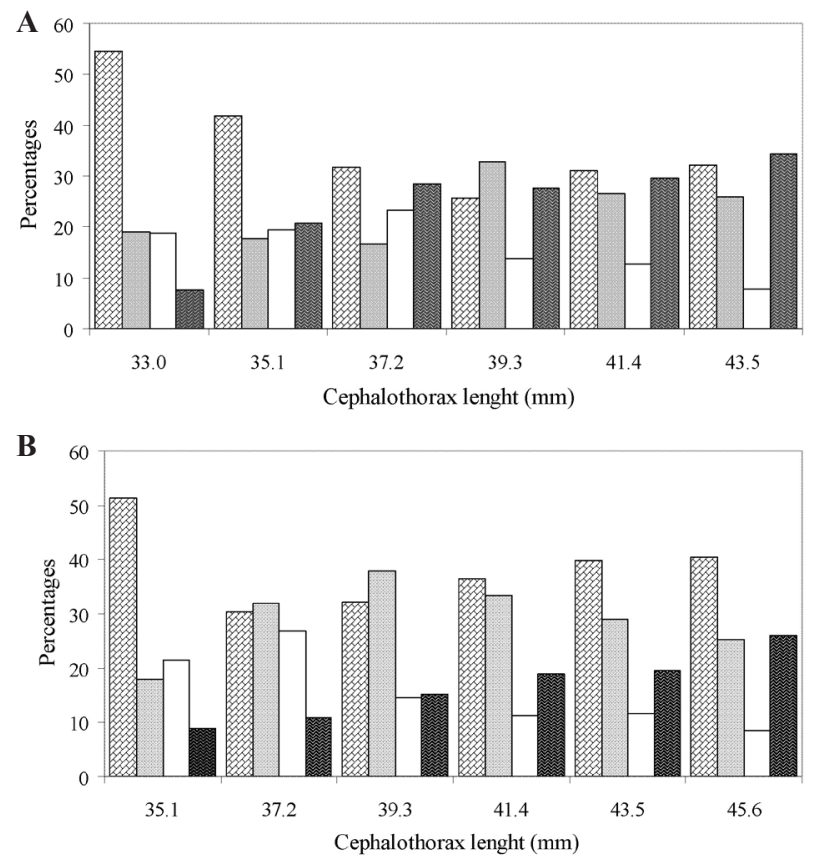

Figures 4. Percentages of cysts of Microphallus nicolli by development stage of cysts and size-classes of female crabs (Emerita rathbunae). Hatched bars = immature cysts; Shaded bars = late immature cysts; Open bars = mature cysts; Dark bars $=$ melanized cysts. Data are only from San Andrés (A) and Las Trancas beaches (B). Stages of cyst maturity were modified from Keeney et al. (2007).
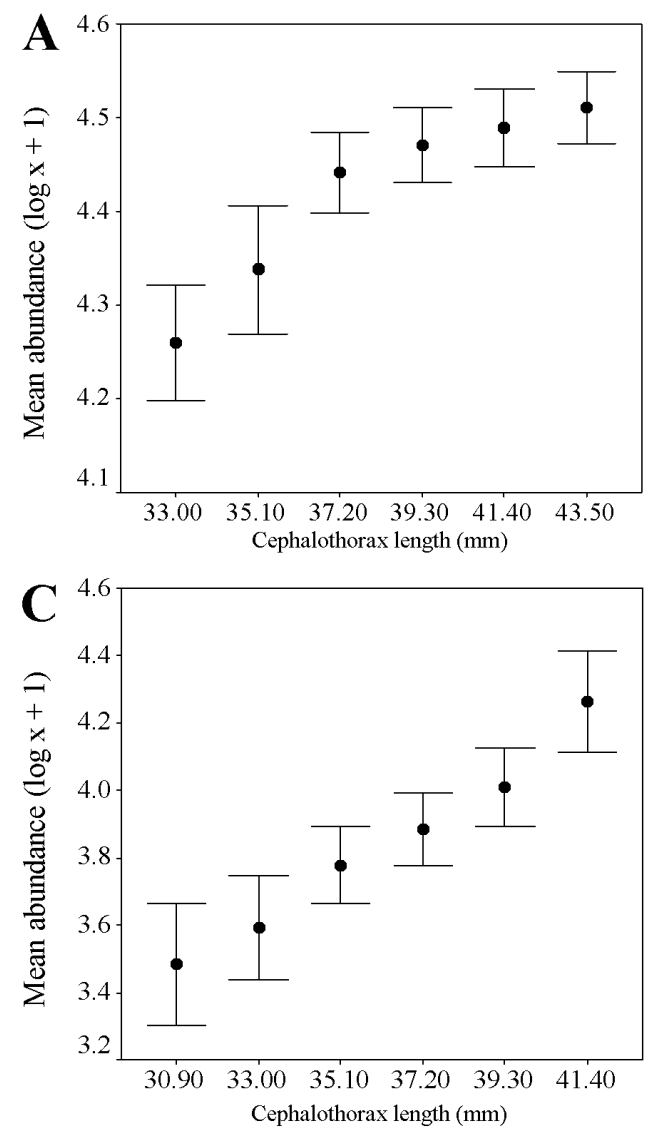
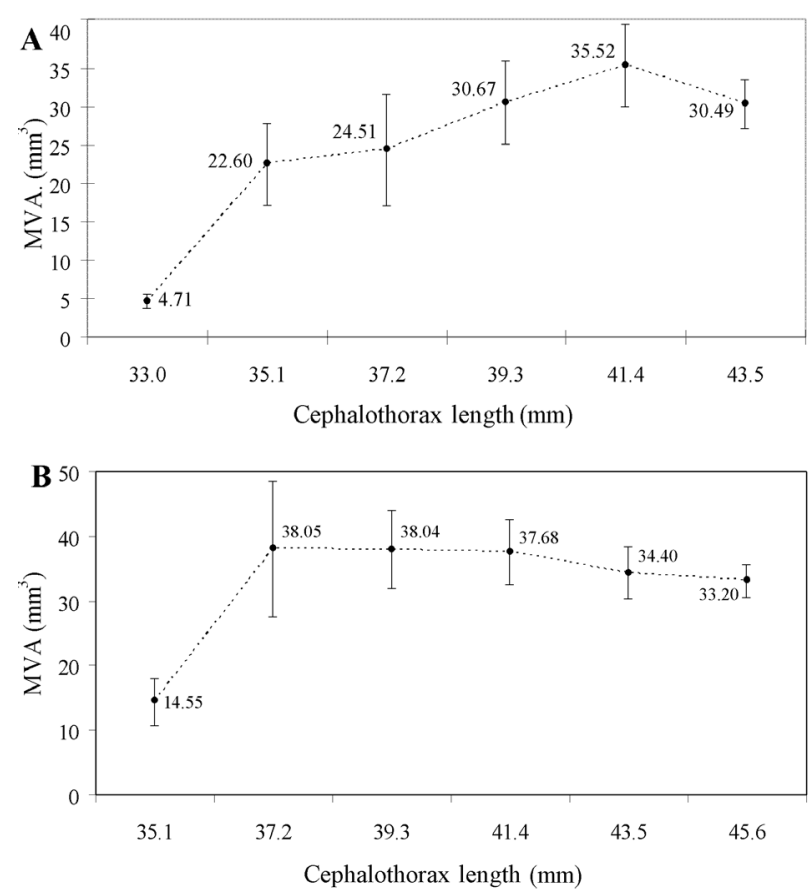

Figure 5. Relationship between mean abundance of cysts of $\mathrm{Mi}$ crophallus nicolli calculated from volumetric measurements and the cephalothorax length of females of Emerita rathbunae. Data are from only San Andrés (A) and Las Trancas beaches (B).
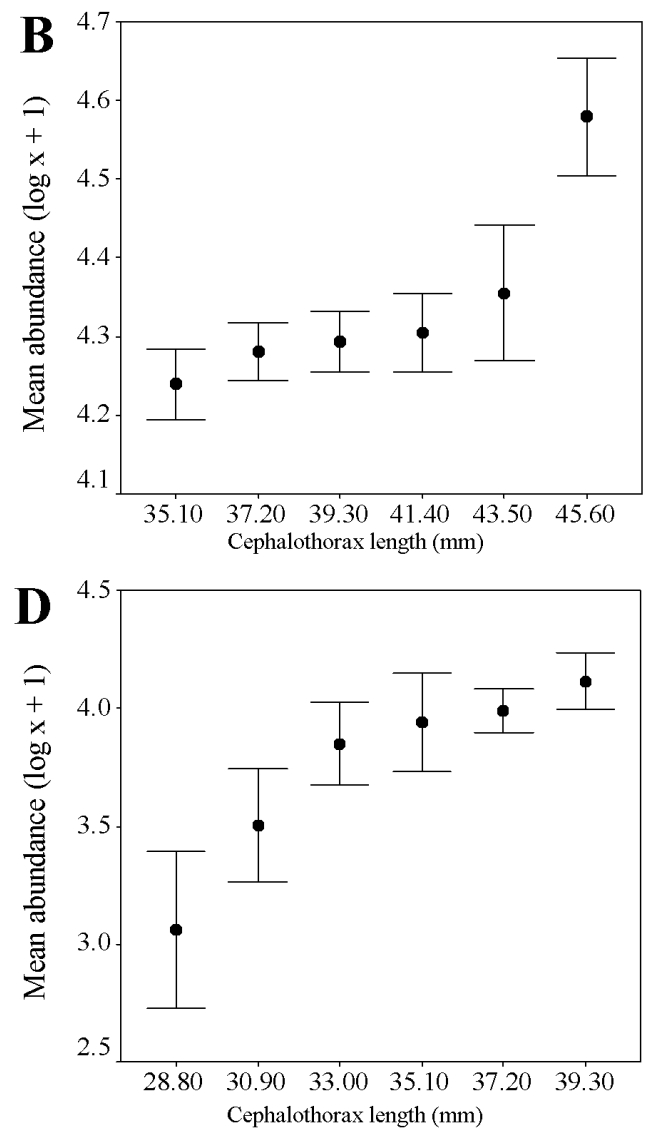

Figure 6. Relationship between mean abundance of cysts $(\log x+1)$ of Microphallus nicolli and size-classes of females of Emerita rathbunae based on cephalothorax length. Data are for all four localities: San Andrés (A), Revolcadero (B), Las Trancas (C), and Ixtapa (D). 
Table 2. Mean length and width measurements and the volume $\left(\mathrm{mm}^{3}\right)$ of encysted metacercariae of Microphallus nicolli by development stage. Global percentage of melanized cysts corresponds to the sum of the percentages found in the three stages.

\begin{tabular}{l|c|c|c|c|c|c}
\hline \multicolumn{1}{c|}{ Cyst stage } & No. of cysts & Length $\mathbf{( m m )}$ & Width $\mathbf{( m m )}$ & $\begin{array}{c}\text { Volume } \\
\left(\mathbf{m m}^{3}\right)\end{array}$ & $\begin{array}{c}\text { Global percentage of } \\
\text { melanized cysts }\end{array}$ & $\begin{array}{c}\text { Mean number of } \\
\text { melanized cysts }\end{array}$ \\
\hline Immature & 247 & $0.259 \pm 0.040$ & $0.221 \pm 0.034$ & 0.0066 & $37 \%$ & 91.4 \\
\hline Late immature & 233 & $0.350 \pm 0.038$ & $0.301 \pm 0.035$ & 0.0166 & $26 \%$ & 86.2 \\
\hline Mature & 151 & $0.591 \pm 0.046$ & $0.393 \pm 0.038$ & 0.0477 & $16 \%$ & 55.9 \\
\hline Melanized cyst & 235 & $0.317 \pm 0.062$ & $0.269 \pm 0.044$ & 0.0125 & $21 \%$ &.. \\
\hline
\end{tabular}

of final and intermediate host (Iannacone et al. 2007; Latham and Poulin 2002b; Latham and Poulin 2002c; Oliva et al. 2008; Smith 2007). In this study area, a possible first intermediate host for M. nicolli is the snail Agaronia testacea (Lamarck, 1811), and the probable final hosts are coastal marine birds; species of Scolopacidae and Recurvirostridae (Charadriiformes); members of Tringa and Numenius are known to actively feed on E. rathbunae (Violante-González et al. 2012; Violante-González et al. 2015). However, to date, no studies have been made to identify precisely the definitive host of M. nicolli in Guerrero.

It is possible that variation in the abundance of $M$. nicolli between the four locations is the result of a factor or process related to the size of the crabs that might influence this infection parameter (Poulin 1999). A positive correlation between crab size and abundance was observed at all four locations (Table 1), with mean abundance highest in crabs from San Andrés and Las Trancas (Table 1). However, this tendency also is consistent with the hypothesis that largest crabs (i.e., older) have accumulated parasites for a longer period of time. Individuals of $E$. analoga can to live up to 3.5 years (Oliva et al. 2008), so individuals of that species accumulate large quantities of helminths during their lifetime. In our study, it was not possible to determine the strength of a simple age-infrapopulation size effect because the maximum age/size of E. rathbunae has not been documented, but our results are similar to the mortality seen in studies of E. analoga (Alvitres et al. 1999; Iannacone et al. 2007; Oliva et al. 2008; Oliva et al. 1992; Smith 2007) and other shore crabs (Latham and Poulin 2002a; Latham and Poulin 2002b).

Metacercaria of $M$. nicolli continue to grow post-encystment (Peoples and Poulin 2011; Pina et al. 2011), and we found that size of cysts differed according to developmental stage (Table 2). Mean volume of immature (small) cysts was $0.0066 \mathrm{~mm}^{3}$, and the volume of mature cysts was $0.0477 \mathrm{~mm}^{3}$, representing an increase from initial volume of up to $700 \%$ during encystment inside the crabs. However, the mean number of cysts/crab decreased with developmental stage $(247,233$, and 151, respectively). We interpret this as support for increased mortality of crabs as metacercariae develop. There are no studies of the histopathology caused by these helminths, but the increase in volume of metacercariae undoubtedly damages the tissues of the crabs. It also is not known if the size of metacercaria is linked directly to the size of crabs (Ruiz-Daniels et al. 2013). These are areas for further research.

A high percentage of cysts had been encapsulated and melanized (Table 2). This process, encapsulation and subsequent cellular melanization of metacercariae, is a common response of the host's immune system in crustaceans, and it results in the death of the metacercaria (Keeney et al. 2007; Koehler and Poulin 2010). Immature cysts frequently were melanized more than were those of older stages, and the percentage of melanized immature cysts increased progressively from the smallest to the largest crab size classes (Fig. 4A, 4B). This suggests that the immunologic response in E. rathbunae is age-dependent; i.e., through this response larger (older) crabs can eliminate a large percentage of recently-introduced parasites, thus slowing greater accumulation of parasites and concurrent mortality (Keeney et al. 2007; Koehler and Poulin 2010). As well, the mean number of melanized cysts decreased with developmental stage; we cannot explain this decrease in number and there is no available evidence that the melanized cysts eventually were absorbed by the crabs. There also is no information on the potential for genetically mixed populations of $M$. nicolli (brought to these beaches by birds from completely different regions), although this is likely. This could confound our results if there are different immune responses to different strains, as was seen by Koehler et al. (2011). Molecular studies of individual helminths (DNA fingerprinting) should be carried out in the future to resolve this issue.

The overall percentage of mature (large) cysts was lower than the percentage of the two earlier stages (Table 2), which could be attributed to larger cysts requiring more nutrients for growth, thus causing death of immature stages, although there is no direct evidence for this. Intraspecific competition for resources at high cyst concentrations ( 800 to 2000 cysts in the present study) in the same structure (hepatopancreas) could be causing cyst death. Density-dependent effects acting on regulation of metacercarie growth are common in marine crustacean hosts (Fredensborg and Poulin 2005; Keeney et al. 2007), although more study is necessary to elucidate direct and indirect causes. This regulator effect on survival of parasites according to size may be very important for $M$. nicolli because, unlike many other microphallid larvae, it grows several hundred times its initial volume inside the second intermediate host (Fredensborg et al. 2004; Keeney et al. 2007; Koehler and Poulin 2010; Latham and Poulin 2002b). 
Ample evidence exists of parasite-induced mortality in marine crustacean populations under field conditions (Fredensborg et al. 2004; Koehler and Poulin 2010; Latham and Poulin 2002b; Thomas et al. 1995). Parasite-induced host mortality can be deduced by means of a decrease in infection intensity in older hosts, which we observe in our data. Using an acanthocephalan/crab system, Latham and Poulin (2002) suggested that reductions in mean parasite numbers in the largest crab size-classes could be attributed to the loss of heavily-infected individuals; this also was observed in our data. With a similar approach, Koehler and Poulin (2010) reported host mortality in four species of crab from New Zealand, and they concluded that this was induced by two microphallids (Maritrema novaezealandensis and Microphallus sp.).

If an infrapopulation of a species of parasite does not induce host mortality, then a positive linear relationship can be expected between host size and parasite abundance due to parasite accumulation in the host over time (Koehler and Poulin 2010). In the data presented herein, polynomial (curvilinear) regressions had a better fit to mean abundance data per crab size-classes at all four locations (Table 3 ) than linear regressions. However, the curves generated were of two types; concave and convex. For Revolcadero and Las Trancas, the best-fit curves were concave (Fig. $6 \mathrm{~A}, \mathrm{D})$, suggesting an increase in parasite load with crab size surpassing a linear relationship. The regression curves for San Andrés and Ixtapa were convex (Fig. 6B, C), indicating a reduction in parasite load in the largest (oldest) size classes. The latter could be attributed directly to death of those hosts harboring greater numbers of parasites and removal of both host and parasites from the population of crabs. It is interesting that these differences do not appear to be related to parasite intensity (Table 1).

In some studies of host mortality induced by helminth parasites, differences have been reported in the effect of parasites between host species and locations (Koehler and Poulin 2010; Latham and Poulin 2002b). These differences have been attributed to possible host manipulation by the parasites in order to increase the likelihood of predation by definitive hosts, and the presence of the final host (i.e., shorebirds) in locations where host population regulation was studied. Although several species of Microphallus can manipulate host behavior (Hansen and Poulin 2005; Ruiz-Daniels et al. 2013; Thomas et al. $1995)$, there have been no studies of the possibility of infected individuals of E. rathbunae being manipulated by M. nicolli. There is, however, a high abundance of marine coastal birds at San Andres (unpublished data) that could cause heavy predation of larger, highly-infected crabs, and, during this study, migratory birds were observed catching and eating crabs on these beaches. This might explain the possible host population regulation suggested by the regression analysis (Table 3 ) and the mean parasite abundance vs. crab size class graph (Fig. 6A). This is not the case for Ixtapa, although the statistical analyses also indicated a reduction in the parasite load in the largest size classes of crab (Fig. 6D). The number of birds
Table 3. Results of the regression analysis used to evaluate the relationship between number of cysts of Microphallus nicolli $(\log x+1)$ per crab and the cephalothorax length of crabs from four coastal locations in Guerrero, Mexico. $n=$ number of crabs that were examined; $\mathrm{R}^{2}=$ coefficient of determination; $\mathrm{P}=$ significance level. Note: $100 \%$ of the crabs examined were infected.

\begin{tabular}{l|c|c|c|c|c|c}
\hline & & \multicolumn{2}{|c|}{ Linear } & \multicolumn{3}{c}{ Polynomial } \\
\hline \multicolumn{1}{c|}{ Locality } & $\mathbf{n}$ & $\mathbf{R}^{\mathbf{2}}$ & $\mathbf{P}$ & $\mathbf{R}^{\mathbf{2}}$ & $\mathbf{P}$ & Curve type \\
\hline San Andrés & 146 & 0.297 & 0.0001 & 0.330 & 0.0001 & Convex \\
\hline Revolcadero & 114 & 0.393 & 0.0001 & 0.395 & 0.0001 & Concave \\
\hline Las Trancas & 173 & 0.235 & 0.0001 & 0.300 & 0.0001 & Concave \\
\hline Ixtapa & 68 & 0.508 & 0.0001 & 0.588 & 0.0001 & Convex \\
\hline
\end{tabular}

visiting that beach noticeably was less, probably due to constant tourist traffic, which would directly affect the parameters of the helminth population in E. rathbunae.

The most plausible explanation for the lower abundance of metacercaria in larger size crabs is the regulation of the population of E. rathbunae through elimination of a high proportion of metacercariae cysts, directly by mortality of crabs or by favoring the capture of the more highly-infected crabs (the larger, older hosts) (Keeney et al. 2007; Koehler and Poulin 2010). As we observed, E. rathbunae can eliminate/inactivate a considerable percentage of cysts through melanization, most of which are immature. The largest crabs may have a stronger immune response, allowing them to eliminate a greater number of cysts by encapsulation, followed by melanization, and eventual metacercariae death (Keeney et al. 2007; Koehler and Poulin 2010), but these would have to be absorbed by the crabs and disappear from the infrapopulation of metacercaria because the percentage decreases rather than increases. In that sense, the decline in aggregation levels of $M$. nicolli observed in the largest size-classes of crabs at most locations (Fig. 6A-D) would be attributed to the reduction in the abundance of metacercariae caused by higher cyst mortality in larger crabs. The reductions in mean volumetric metacercariae abundance in the largest size-classes at both San Andrés and Las Trancas (Fig. 5A, B) resulted from the number of large, mature cysts in these crab size-classes without overall increase in infrapopulation size. Interestingly, host population regulation by parasites is thought be nearly impossible when parasites are highly aggregated in the host (Poulin and Morand 2000).

\section{Conclusions}

Parasite-induced mortality in populations of a marine crustacean (E. rathbunae) under field conditions by infrapopulations of the metacercaria of $M$. nicolli is documented in four populations of sand crabs in Guerrero, Mexico. These results are consistent with previous studies of other Crustacea-Digenea host-parasite systems. Evidence that the population of E. rathbunae is affected, and possibly regulated, by the infrapopulations of 
$M$. nicolli consists of five factors: 1 . Mean volumetric abundance of metacercariae generally decreased as crabs aged (grew larger), but the proportion of mature cysts decreased, suggesting that the metacercariae were growing, but that crabs with a higher proportion of more mature cysts had been removed (preferentially?) from the population of crabs; 2 . Linear and polynomial regressions of mean abundance of helminths $(\log x+1)$ vs. cephalothorax length of crabs were significant for the four populations of E. rathbunae (Table 3); 3. Although both the linear and polynomial regressions were highly significant, the polynomial regressions had a higher coefficient of determination $\left(\mathrm{r}^{2}\right)$ values, indicating that curvilinear regressions provided a better fit to the data and confirming that selective mortality of hosts was occurring; 4. A positive correlation between crab size and abundance of helminths was observed at all four locations, confirming the potential for host population regulation and/or manipulation of host behavior (favoring transmission) by parasites; and, 5. The mean number of melanized (dead) cysts decreased with the age of the crabs, confirming that crabs either were eliminating substantial numbers of parasites throughout their lifetime or more heavily-infected crabs were being removed from the populations, but direct causes of the decrease could not be identified. The next steps in this study should be to evaluate the genetic composition of the infrapopulations and the metapopulations of $M$. nicolli in order to confirm or reject differential effects at some locations caused by genetic differences. As well, possibility of histopathology should be evaluated to determine if it, rather than behavior modification, is the cause of the changes in mean abundance between size classes of crabs and the decrease in melanized cysts in larger crabs.

\section{Acknowledgements}

Funds for this study were provided to the authors by the Programa de Mejoramiento del Profesorado (PROMEP) as part of the collaborative project "Calidad ambiental y desarrollo sustentable: evaluación del impacto ambiental por actividades antropogénicas- alternativas de mitigación" (third year). Other funds (to JV-G) were provided by the project "Parásitos de rayas de importancia económica y ecológica en la Bahía de Acapulco, Gro.”, financed by the Universidad Autónoma de Guerrero, and the project "Fortalecimiento del Doctorado en Ciencias Ambientales de la Universidad Autónoma de Guerrero", financed by Fondos Mixtos-Consejo Nacional de Ciencia y Tecnología (CONACyT)-Guerrero (2015). Guadalupe Quiterio-Rendón assisted with the processing of much of the material as part of her MS thesis project; she received a scholarship (No. 247514) from CONACyT during this study. The authors wish to thank students of the Marine Ecology Academic Unit (UAG) for their assistance with field and laboratory work, and the local residents who assisted with collection of the crabs.

\section{References}

Alvitres V, Chanamé J, Fupuy J, Chambergo A, Cortez M (1999) Cambios en la prevalencia de los helmintos parásitos de Emerita análoga [sic.] por efecto de "E1 Niño 1997-98”. Revista Peruana de Biología Volumen extraordinario Facultad de Ciencias Biológicas-UNMSM, Lima, Perú, December 1999: 69-76

Bryan-Walker K, Leung TF, Poulin R (2007) Local adaptation of immunity against a trematode parasite in marine amphipod populations. Marine Biology 152(3): 687-695 doi: 10.1007/s00227-007-0725-x

Bush AO, Lafferty KD, Lotz JM, Shostak AW (1997) Parasitology meets ecology on its own terms: Margolis et al. revisited. Journal of Parasitology 83(4): 575-583 doi: 10.2307/3284227

Fredensborg BL, Mouritsen KN, Poulin R (2004) Intensity-dependent mortality of Paracalliope novizealandiae (Amphipoda: Crustacea) infected by a trematode: experimental infections and field observations. Journal of Experimental Marine Biology and Ecology 311(2004): 253-265 doi: 10.1016/j.jembe.2004.05.011

Fredensborg BL, Poulin R (2005) Larval helminths in intermediate hosts: does competition early in life determine the fitness of adult parasites? International Journal for Parasitology 35(10): 1061-1070. doi: 10.1016/j.ijpara.2005.05.005

Hansen EK, Poulin R (2005) Impact of a microphallid trematode on the behaviour and survival of its isopod intermediate host: phylogenetic inheritance? Parasitology Research 97(3): 242-246. doi: 10.1007/ s00436-005-1435-2

Hendrickx, ME, Harvey AW (1999) Checklist of Anomuran crabs (Crustacea: Decapoda) from the Eastern Tropical Pacific. Belgian Journal of Zoology 129(2): 363-389.

Iannacone J, Alvariño L, Bolognesi B (2007) Aspectos cuantitativos de los metazoos parásitos del muy muy Emerita analoga (Stimpson) (Decapoda: Hippidae) en Chorrillos, Lima, Peru. Neotropical Helminthology 1(2): 59-67.

Keeney DB, Waters JM, Poulin R (2007) Diversity of trematode genetic clones within amphipods and the timing of same-clone infections. International Journal for Parasitology 37(3-4): 351-357 doi: 10.1016/j.ijpara.2006.11.004

Koehler AV, Gonchar AG, Poulin R (2011) Genetic and environmental determinants of host use in the trematode Maritrema novaezealandensis (Microphallidae). Parasitology 138(01): 100-106. doi: 10.1017/S0031182010001022

Koehler AV, Poulin R (2010) Host partitioning by parasites in an intertidal crustacean community. Journal of Parasitology 96(5): 862868. doi: $10.1645 / \mathrm{GE}-2460.1$

Latham ADM, Poulin R (2002a) Effect of acanthocephalan parasites on hiding behaviour in two species of shore crabs. Journal of Helminthology 76(04): 323-326 doi: 10.1079/JOH2002139

Latham ADM, Poulin R (2002b) Field evidence of the impact of two acanthocephalan parasites on the mortality of three species of New Zealand shore crabs (Brachyura). Marine Biology 141: 1131-1139. doi: 10.1007/s00227-002-0913-7

Latham ADM, Poulin R (2002c) New records of gastrointestinal helminths from the southern black-backed gull (Larus dominicanus) in New Zealand. New Zealand Journal of Zoology 29(3): 253-257. doi: 10.1080/03014223.2002.9518309

Oliva ME, Barrios I, Thatje S, Laudien J (2008) Changes in prevalence and intensity of infection of Profilicollis altmani (Perry, 1942) cystacanth (Acanthocephala) parasitizing the mole crab Emerita analoga 
(Stimpson, 1857): an El Niño cascade effect? Helgoland Marine Research 62(1): 57-62. doi: 10.1007/s10152-007-0082-7

Oliva ME, Luque JL, Cevallos A (1992) Parásitos de Emerita analoga (Stimpson) (Crustacea): implicancias ecológicas. Boletin de Lima 79: 77-90.

Peoples RC, Poulin R (2011) Encystment patterns and metacercarial size of an opecoelid trematode in two polychaete hosts. Parasitology Research 109(3): 865-870. doi: 10.1007/s00436-011-2313-8

Pina S, Riussell-Pinto F, Rodrigues P (2011) Morphological and molecular study of Microphallus primas (Digenea: Microphallidae) metacercaria, infecting the shore crab Carcinus maenas from northern Portugal. Folia Parasitologica 58(1): 48-54. doi: 10.14411/fp.2011.005

Poulin R (1999) Body size vs abundance among parasite species: positive relationships? Ecography 22(3): 246-250. doi: 10.1111/j.16000587.1999.tb00499.x

Poulin R, Morand S (2000) Parasite body size and interspecific variation in levels of aggregation among nematodes. Journal of Parasitology 86(3): 642-647. doi: 10.1645/0022-3395(2000)086[0642: PBSAIV]2.0.CO;2

Pritchard MH, Kruse GOW (1982) The collection and preservation of animal parasites, Technical Bulletin No. 1, The Harold W. Manter Laboratory. University of Nebraska Press, Lincoln, Nebraska.

Ríos-Elósegui D, Hendrickx ME (2015) Abundance, relative growth and fecundity of Emerita rathbunae Schmitt, 1935 (Decapoda, Anomura, Hippidae) in the S.E. Gulf of California, Mexico. Crustaceana 88(2): 127-143. doi: 10.1163/15685403-00003400

Robaldo RB, Monserrat J, Cousin JCB, Bianchini A (1999) Effects of metacercariae (Digenea: Microphallidae) on the hepatopancreas of Chasmagnathus granulata (Decapoda: Grapsidae). Diseases of Aquatic Organisms 37: 153-157. doi: 10.3354/dao037153
Ruiz-Daniels R, Beltran S, Poulin R, Lagrue C (2013) Do parasites adopt different strategies in different intermediate hosts? Host size, not host species, influences Coitocaecum parvum (Trematoda) life history strategy, size and egg production. Parasitology 140(2): 275283. doi: $10.1017 /$ S0031182012001564

Smith NF (2007) Associations between shorebird abundance and parasites in the sand crab, Emerita analoga, along the California coast. Journal of Parasitology 93(2): 265-273. doi: 10.1645/GE-1002R.1

Studer A, Poulin R (2012) Seasonal dynamics in an intertidal mudflat: the case of a complex trematode life cycle. Marine Ecology Progress Series 455: 79-93. doi: 10.3354/meps09761

Tam YK, Kornfield I, Ojeda FP (1996) Divergence and zoogeography of mole crabs, Emerita spp. (Decapoda: Hippidae), in the Americas. Marine Biology 125(3): 489-497. doi: 10.1007/bf00353262

Thomas F, Renaud F, Rousset F, Cezilly F, de Meeûs T (1995) Differential mortality of two closely related host species induced by one parasite. Proceedings of the Royal Society of London (B) 260(1359): 349-352. doi: 10.1098/rspb.1995.0103

Violante-González J, Quiterio-Rendón G, Larumbe-Morán E, Gil-Guerrero S, Rojas-Herrera AA, Carbajal-Violante J (2012) Impacto del parasitismo en la mortalidad del "Chiquilique" Emerita analoga (Anomura: Hippidae), en 3 localidades del estado de Guerrero, México. Tlamati 4: 14-21.

Violante-González J, Quiterio-Rendon G, Monks S, García-Ibañez S, Pulido-Flores G, Rojas-Herrera AA, Larumbe-Moran E (2015) Parasite communities of the Pacific mole crab, Emerita rathbunae (Anomura: Hippidae), in sandy beaches from Guerrero and Michoacán, Mexico. Open Journal of Marine Science 5(4): 468-476. doi: 10.4236/ojms.2015.54037 